Research article

\title{
Using modeling tools for implementing feasible land use and nature conservation governance systems in small islands - The Pico Island (Azores) case-study
}

\author{
J.P. Fernandes ${ }^{\text {a, b }}$, M. Freire ${ }^{\text {b, c }}$, N. Guiomar ${ }^{\text {a, b, }}{ }^{*}$, A. Gil ${ }^{\mathrm{d}}$ \\ a ICAAM - Instituto de Ciências Agrícolas e Ambientais Mediterrânicas, Universidade de Évora, Portugal \\ b Departamento de Paisagem, Ambiente e Ordenamento, Universidade de Évora, Portugal \\ c e-GEO Centro de Estudos de Geografia e Planeamento Regional, Faculdade de Ciências Sociais e Humanas, Universidade Nova de Lisboa, Portugal \\ d $\mathrm{Ce} 3 \mathrm{C}$ - Centre for Ecology, Evolution and Environmental Changes, Azorean Biodiversity Group, University of the Azores (Faculty of Sciences and \\ Technology, Department of Biology), Ponta Delgada, Portugal
}

\section{A R T I C L E I N F O}

\section{Article history:}

Received 12 April 2016

Received in revised form

19 November 2016

Accepted 12 December 2016

\section{Keywords:}

Planning units

Nature conservation

Conservation targets

Conservation trade-offs

Island National Park (INP)

\begin{abstract}
A B S T R A C T
The present study deals with the development of systematic conservation planning as management instrument in small oceanic islands, ensuring open systems of governance, and able to integrate an informed and involved participation of the stakeholders. Marxan software was used to define management areas according a set of alternative land use scenarios considering different conservation and management paradigms. Modeled conservation zones were interpreted and compared with the existing protected areas allowing more fused information for future trade-outs and stakeholder's involvement. The results, allowing the identification of Target Management Units (TMU) based on the consideration of different development scenarios proved to be consistent with a feasible development of evaluation approaches able to support sound governance systems. Moreover, the detailed geographic identification of TMU seems to be able to support participated policies towards a more sustainable management of the entire island.
\end{abstract}

๑) 2016 Elsevier Ltd. All rights reserved.

\section{Introduction}

Currently, nature conservation faces important challenges, particularly with the growing recognition of the traditional protected areas-based paradigm's inability to reverse or, at least, to slow down the rate of biodiversity loss and also its incapability to act on the main factors of disturbance (Wiens, 2009; GómezBaggethun and Ruiz-Pérez, 2011; Mora and Sale, 2011). While this situation has been addressed by proposing alternative strategies (e.g. Lindenmayer et al., 2008; Seastedt et al., 2008; Hobbs et al., 2009), a dichotomy between natural areas and places more or less disturbed (or "degraded") persists, making it difficult to implement an integrated approach to conservation planning and management.

In the microcosm of small oceanic islands these issues are still more relevant, because the identification and assessment of values

\footnotetext{
* Corresponding author.

E-mail address: nunogui@uevora.pt (N. Guiomar).
}

and threats has to consider criteria, perspectives and systems of values different from those adopted in mainland systems (Fernandes et al., 2014, 2015). This is due to the higher susceptibility and vulnerability of these territories to ecological disturbances (e.g. Pelling and Uitto, 2001; Calado et al., 2011; Fragoso et al., 2012; Nunn and Carson, 2015), the lower resilience of the islands limited species number and gene pool and, consequently, the higher levels of extinction debt (Frankham, 1998; Ricketts et al., 2005; Triantis et al., 2010; Mora et al., 2012). These problems imply management approaches able to combine human aspirations with the preservation of viable ecological communities and the prevention of invasion by alien species, ensuring simultaneously higher ecosystem resilience (Craig, 1990; Daugherty et al., 1990; Francisco-Ortega et al., 2000; Lane, 2007; Reaser et al., 2007; Caujapé-Castells et al., 2010). The research project SMARTPARKS, in which this study is embedded, aimed at analyzing this problematic (Calado et al., 2014).

These issues imply the recognition of humans as an integral and critical part of these ecosystems, and the need to develop innovative knowledge-based adaptive management approaches (Wiens, 
2007). Cumulatively, the dynamics of social, ecological and economic conditions, and the growing awareness by residents of the complex nature of their islands social-ecological systems, imply that the management processes in islands contexts have to be based on strongly effective instruments of adaptive governance (Folke et al., 2005; Heuer, 2011; Schwarz et al., 2011; Rijke et al., 2012; Aretano et al., 2013).

Thus, management towards nature conservation and ecosystem restoration becomes a core issue, being therefore necessary to identify what are the critical areas for conservation (e.g. Lagabrielle et al., 2009) and balance them with a viable economic management of the island in a con conflictive basis contributing to the protection and enhancement of conservation values. This objective implies the development of new governance frameworks, consensual trade-off mechanisms, contracts on resources allocation and management guidelines, innovative management practices and accountable decision-making procedures able to build a more consensual and participated island management policy (e.g. Costanza et al., 2007; van Beukering et al., 2007; Lagabrielle et al., 2010; Fonseca et al., 2011; Fernandes et al., 2015).

This paper's main goal is to prove the feasibility of developing such instruments able to evaluate and compare different management scenarios and their contribution to the preservation and even increase of the conservation value of terrestrial island's ecosystems. This is achieved through the use of well-tested models to perform the simulation of different land use scenarios and the assessment of their costs and benefits at the island scale, making possible to better define management practices aiming at a more integrated and sustainable island conservation policy. Such models may allow a sounder stakeholder involvement by integrating their different values and perspectives into the process, based on a comprehensible evaluation of the costs and benefits of each management alternative. We explore these models not only in order to identify conservation areas, but to compare the gains and costs of alternative management scenarios and then, identify Target Management Areas. The obtained results proved the ability of these approaches to sustain sustained participatory trade-off mechanisms in the context of the island integrated management.

\section{Materials and methods}

\subsection{Study area}

The Azores archipelago, the youngest within the Macaronesian region (Fernández-Palacios et al., 2011), comprises nine volcanic islands (Fig. 1a) and numerous small islets and seamounts. The Azorean islands are located on the Mid-Atlantic Ridge over $1600 \mathrm{~km}$ from Portuguese mainland and $1900 \mathrm{~km}$ from North America (Fig. 1b).

This study was the Pico Island (Fig. 1c) which is the second largest island $\left(447.74 \mathrm{~km}^{2}\right)$ of the Azorean archipelago. A large part of the island and surrounding waters are included in the Pico Island Natural Park (INP) (Fig. 1c). This administrative figure includes and articulates all conservation areas of the island into a single management structure and policy definition system and authority (Fonseca et al., 2011).

Geomorphology determines the main characteristics and zonation of the island (Dias et al., 2007). The predominant soils are Andisols. The climate is temperate oceanic with short annual temperature amplitudes (Azevedo et al., 1999). Elevation has a strong effect on rainfall distribution, ranging from 1000 to $1900 \mathrm{~mm}$ in the first $100 \mathrm{~m}$, to more than $4000 \mathrm{~mm}$ above $700 \mathrm{~m}$, and snowfall can occur above $2000 \mathrm{~m}$. The average relative humidity throughout the year is of about $80 \%$, tending to increase with altitude, which can be related with fog and stationary clouds between 700 and $1800 \mathrm{~m}$. The Pico island presents the highest plant diversity in the archipelago, mainly due to a higher number of altitudinal vegetation belts derived from its altitude (up to $2345 \mathrm{~m}$ ) (Tutin, 1953; Haggar, 1988; Dias et al., 2005).

Most of the island has low disturbance levels and land use intensity (predominantly extensive cattle grazing). The exception is the coastal fringe being subject to an intense urban pressure. Analyzing the present land uses, it is possible to verify the dominance of pasture and important remains of Erica azorica, as well as some relevant patches of Myrica faya, indicating therefore a good potential evolution towards natural vegetation communities (Fig. 2). Another important characteristic of Pico's land cover is the dimension and geographical dispersion of deeply disturbed areas invaded by Pittosporum undulatum and Acacia melanoxylon or alien forest stands of Eucalyptus globulus and Cryptomeria japonica. Also important are the vineyards areas that build the "World Heritage Cultural Landscape of the Pico Island Vineyard Culture".

A simple comparison between the land use/land cover map of Pico (Fig. 2) and Pico INP delimitation (Fig. 1c) allows the identification of conflicts derived from the relative importance of extensive pasture areas. Nevertheless, the INP has predominantly low disturbance land uses or vegetation types (without considering the areas invaded by Pittosporum undulatum).

\subsection{Conceptual framework}

The main components and phases of the methodological approach are displayed in Fig. 3 and are based on two main tools. The first one consists of the characterization framework in which the reference for the evaluation process is obtained through the mapping of the stable geographical and environmental resources mainly represented through the natural vegetation that would occur in the present soil conditions should there were no disturbances (reference vegetation) (e.g. Fernandes et al., 2006, 2014). This characterization tool is of critical importance because it allows the identification of stable references for both ecological and socioeconomic systems. The second tool performs the characterization and ecological, economic and societal evaluation of the present land use and/or alternative land use or management scenarios, considering the criteria and interests of the different stakeholders and their respective decision and acting drivers. Both these tools build the basis for the implementation of the management scenario analysis and evaluation.

\subsection{Valuation process (ecological and socio-economic values)}

The critical issue in this methodological approach is the process of value-attribution that builds the basis of the scenario construction and assessment process. The critical values considered were: (1) current and potential conservation value (interest for the preservation and promotion of nature, natural functionality and biodiversity value); (2) societal value (current potential economic and welfare value).

These values cannot be taken as absolute. For example, in the study area, the large majority of the pasture area has no adequate soil productivity and can, even, if inadequately managed, induce degradation trough erosion. Nevertheless the societal value associated with the long-term use (decades or even centuries) of certain areas by the same family or village, is highly relevant to the openness for a trade-off proposal. This is valid for all particular ways in which islanders value each land cover or land use. Another problem, when considering the valuation of conservation variables, is their conservation status. In the context of the present study, the attributed value is primarily based in the existence of a real conservation value (e.g. Natura 2000 habitat) instead of an 

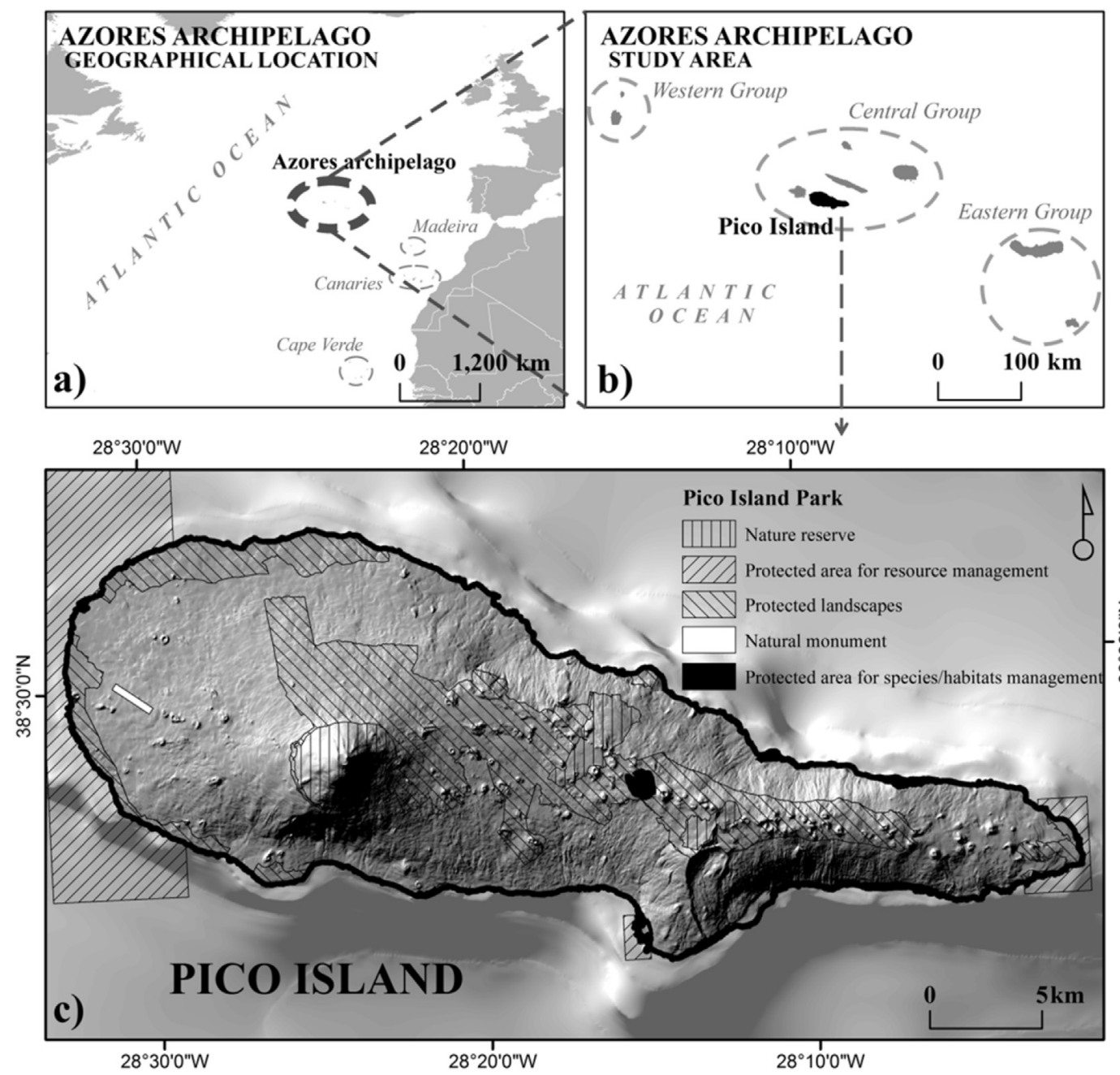

$28^{\circ} 20^{\prime} \mathrm{O}^{\prime \prime} \mathrm{W}$

$w^{\downarrow}$ 


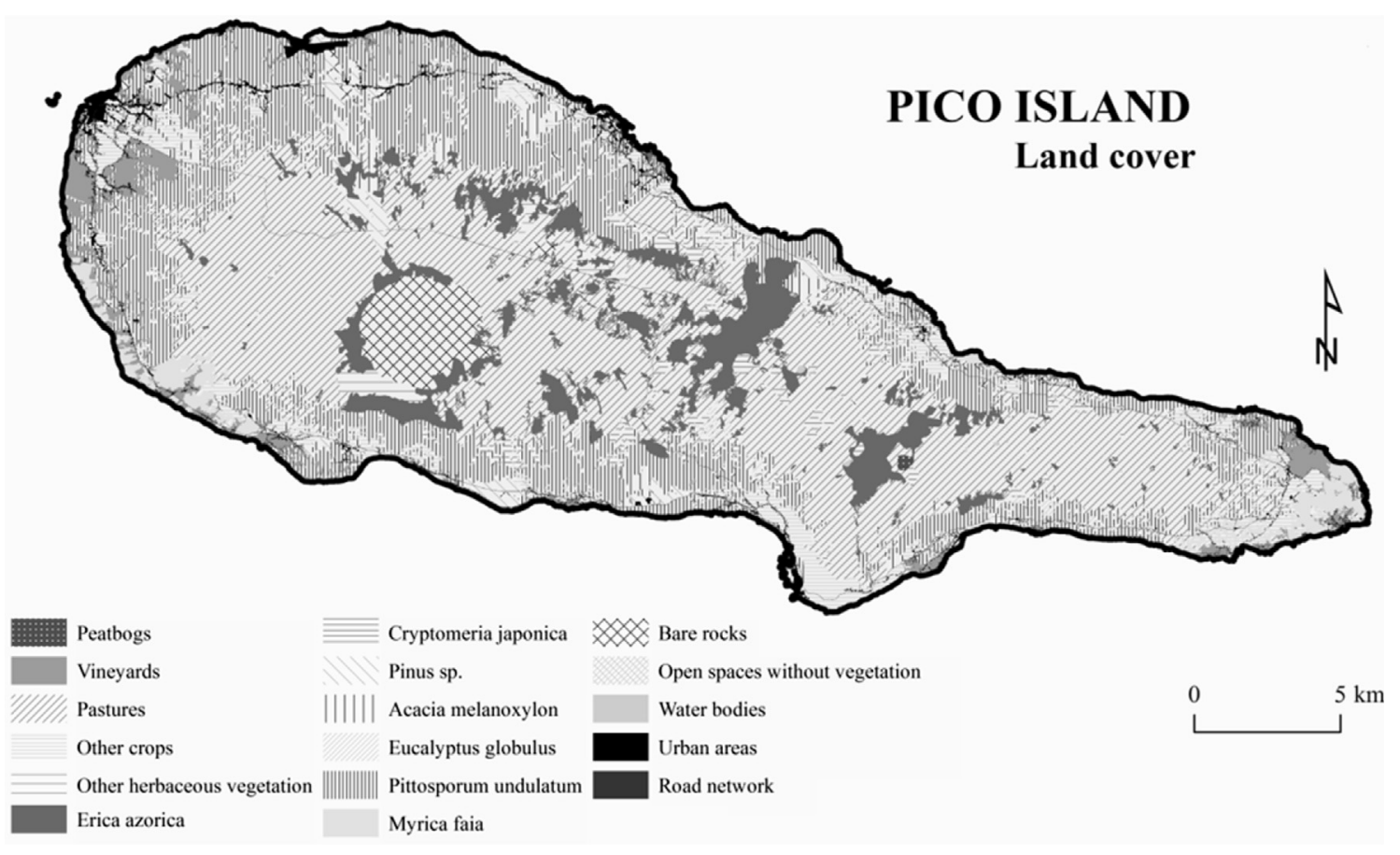

Fig. 2. Land use/Land cover Map of Pico for 2007 (Moreira, 2013).

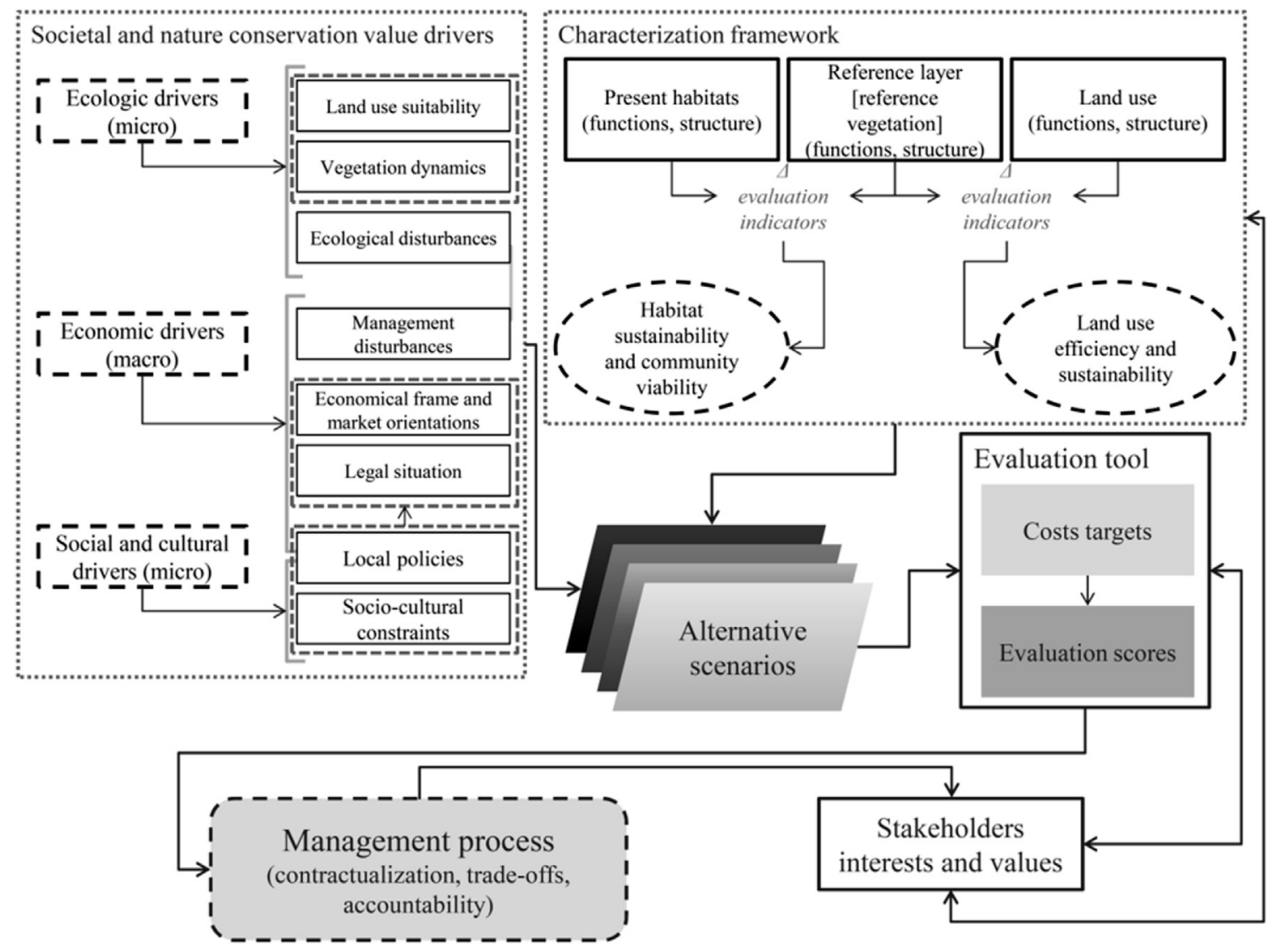

Fig. 3. Main methodological flowchart (adapted from Fernandes et al., 2015).

applying a simulated annealing schedule and a 50-repeat runs in order to produce 50 solutions (e.g. Trindade-Filho et al., 2012). Two outputs were generated: (1) the planning units included in the most efficient portfolio (the best solution) resulting from the spatial 
Table 1

Geographical data of Pico Island used in this research.

\begin{tabular}{ll}
\hline Socio-geographical data & Sources \\
\hline Land use/Land cover map & Moreira (2013) \\
Natural vegetation & Elias et al. (2016); Fernandes et al. (2014); Dias et al. (2005); Tutin (1953) \\
Soil quality & Pinheiro et al. (1987) \\
Societal value & Bragagnolo et al. (2016) \\
\hline
\end{tabular}

optimization used in Marxan; and (2) the irreplaceability score which is the number of times each cell was selected as fulfilling the management targets in a set of runs of the algorithm. For each land use scenario, several BLM values were tested in order to minimize the difference between the selected (cells with irreplaceability score $>40$ ) and the target areas, following an approach based on the Stewart and Possingham (2005) proposal. Global Moran's Index (Moran's I; Moran, 1950) using the Inverse Euclidean Distance and the respectively $z$-score was computed through ArcGIS 10 (ESRI, 2011) to assess the spatial autocorrelation in the irreplaceability scores as a proxy of the spatial compactness of the allocated values. The closer the Moran's $I$ values are to +1 , the higher the spatial autocorrelation is. Z-scores greater than +1.96 or smaller than -1.96 also indicate spatial autocorrelation $(p<0.05)$.

The results were then compared with the current Pico INP boundaries, considering separately the planning units included in the most efficient portfolio and the planning units with the maximum irreplaceability score according to the metrics proposed by Pontius and Millones (2011). Agreement and disagreement metrics derived from quantity and location were thereafter used to compare the selected spatial units with the existing reserves, considering all the conservation-planning scenarios.

\subsection{Scenario analysis}

Different conceptual scenarios were developed for evaluating the possibility of building a simulation instrument able to support the comparison among different management alternatives and then assess the relative trade-offs that may concern each stakeholder. These scenarios (Table 2) are supposed to portray, in a simplified way, the main alternative management approaches that island authorities and inhabitants can face, in order to integrate nature conservation targets and societal interests. Their conception was based on the predominant conservation and landscape management policies and on the perceived stakeholder's sensibility according to the research from the SMARTPARKS project (Bragagnolo et al., 2016).

The first scenario was built in order to represent the current situation in terms of the relative importance given by society to the present land use. In this scenario, "cost" corresponds to the societal cost of changing/loosing that land use, expressed in a scale from 1 to 10 , according to the relative economic and/or cultural importance (based on Bragagnolo et al., 2016). It was also considered, that for the islanders, natural communities of Erica azorica or Myrica faya are not generally deemed relevant. In turn, the value attributed to the "target" corresponded to the interest for nature conservation, i.e., the closer the land cover category is to the reference vegetation, the higher the score. The resulting "costs" and "targets" are presented in Table 3.

The second scenario was developed in order to analyze the hypothesis of giving full priority to ecological restoration and preservation, independently from the economic land value. The target and cost functions were assigned on the basis of the reference vegetation. This was done by attributing to each vegetation unit a conservation value (CV), a Nature conservation cost (NCC) and a protection value (PV). CV value was assigned based on conservation criteria such as rarity, diversity, naturalness, unique character, resilience and threat according to the method developed by Fernandes et al. (2006). The Nature conservation cost (NCC) was assigned as economic value of the present land use, corresponding to the cost from the first scenario, and Protection value (PV) was

Table 3

Values for cost and target for the present land uses used for the first and the third scenario.

\begin{tabular}{lll}
\hline Land use & Cost & Target \\
\hline Natural vegetation & 4 & \\
Myrica faia communities & 4 & 10 \\
Erica azorica communities & 7 & 10 \\
Peatbogs & 5 & 9 \\
Lagoons & 3 & 8 \\
Other herbaceous vegetation & & \\
Other natural areas & 1 & 4 \\
Bare rocks & 2 & 2 \\
Open spaces without vegetation & & 8 \\
Agriculture & 9 & 6 \\
Vineyards & 10 & 5 \\
Pastures & 8 & 3 \\
Other crops & & 3 \\
Production forest & 7 & 1 \\
Pinus spp. stands & 7 & \\
Cryptomeria japonica stands & 7 & -1 \\
Eucalyptus globulus stands & & -1 \\
Infested areas & 1 & 0 \\
Acacia melanoxylon patches & 1 & 0 \\
Pittosporum undulatum woodland & & \\
Infrastructures & 10 & \\
Urban areas & 10 & \\
Road network & & \\
\hline & &
\end{tabular}

Table 2

Modeled scenarios.

Scenario

1 Evaluation of current land use's conservation value

2 Giving absolute priority to conservation

3 Investment in ecological restoration, while maintaining areas of economic importance

4 Investment in ecological restoration, while maintaining areas of economic importance, considering the spatial distribution of soil suitability as well as the need to protect specific habitats
Value factors

Maximization of natural vegetation conservation value and of the costs associated with economic activities

Maximization of reference vegetation value and consideration of restoration cost Maximization of the conservation value related to the reference vegetation, while maintaining the economic value of the key economic activities

Maximization of the conservation value related to the reference vegetation, while maintaining the economic value of the key economic activities. By affecting this economic value to soil quality value as well as by increasing the conservation value of wetlands 
determined in terms of nature conservation interest. As "target", the conservation value was chosen because it should correspond to the goal of a restoration intervention (Table 4), the value "cost" was derived from the sum of both protection value and Nature conservation cost.

The third scenario was developed considering "cost" as the conceptual distance between the current vegetation and ecological conditions, and the expected conditions without disturbances (reference vegetation). This cost definition aims at expressing the effort needed to restore these ecosystems and vegetation patches. Two different types of areas were considered as "targets." For those areas with low economic profitability (cost from the first scenario equal or lower than 5), the target was defined as the difference between the protection value of each vegetation unit (Table 4) and the conservation value of that particular land use (cost in Table 3). For land uses related to high social value (cost of the first scenario higher than 5) the considered target correspond to the conservation value determined for that land use.

The fourth scenario tried to balance the former scenarios by integrating a correction of the societal "cost" through the consideration of soil agricultural aptitude (based on the soil quality map). This was assessed by considering that agricultural areas (vineyards, pastures and other crops) represent a higher cost when covering soils of high suitability and a lower cost when covering poor soils (with the exception of vineyards given their core role within the World Heritage Cultural Landscape). In the areas corresponding to the target habitats for conservation purposes, the "cost" corresponds to their protection value, while as "target" the conservation value was selected.

\section{Results and discussion}

\subsection{BLM selection}

For each scenario, several Boundary Length Modifiers (BLM) values were tested and only those minimizing the difference between the selected and the target areas were selected (bold values in Table 5). The Moran's $I$ allow the consideration of the spatial autocorrelation, where values near to 1 indicate higher spatial clustering in the irreplaceability scores (the very high values of the $\mathrm{z}$-scores also point to high levels of spatial clustering in the results).

\subsection{Evaluation of current land use conservation value}

In the interpretation of the results, we focus only in the last class of the "irreplaceability score" $(>40)$ because it better addresses the issues related to Pico Island small area and degree of conflict between land uses, invading species and natural values. The results illustrated in Fig. 4a and b show that the Pico INP incorporate the most important areas with the exception of the large area of Myrica faya natural forest in the eastern extreme of the island.

This result constitutes a good way to assess the adequacy of the Marxan framework for targeting areas of interest for conservation in the analyzed context (Tallis et al., 2008; Lagabrielle et al., 2009). Nevertheless, when considering these results from a management perspective, it does not give any indication on the interest of

Table 4

Values used to compute nature conservation cost (2nd scenario).

\begin{tabular}{|c|c|c|c|}
\hline Vegetation units (Fernandes et al., 2014) & CV & PV & NCC \\
\hline Plant communities of oligotrophic lagoons & 7 & 8 & 4 \\
\hline Coastal halophilic and chasmophytic communities of escarpments and cliffs & 7 & 7 & 5 \\
\hline Mosaics of halophilic communities and mixed shrubland on volcanic sands & 5 & 6 & 11 \\
\hline Mosaics of halophilic communities and mixed shrubland of Myrica faya and Juniperus brevifolia & 6 & 7 & 12 \\
\hline Transition between halophilic communities and mixed shrubland of Myrica faya, Juniperus brevifolia and Erica azorica & 6 & 7 & 12 \\
\hline Mixed chasmophytic and riparian vegetation & 6 & 6 & 11 \\
\hline Mixed chasmophytic and riparian vegetation with sparse patches of Erica azorica & 6 & 6 & 2 \\
\hline "Cloud Forest" & 9 & 8 & 13 \\
\hline "Cloud Forest" and mixed shrubland on volcanic sands & 9 & 8 & 13 \\
\hline “Cloud Forest” with important patches of Erica azorica shrubland & 9 & 8 & 13 \\
\hline Mosaics of Erica azorica shrubland and Deschampsia foliosa grasslands & 7 & 7 & 9 \\
\hline Mosaics of Erica azorica shrubland, Deschampsia foliosa grasslands, and other shrubs on volcanic sands & 7 & 7 & 9 \\
\hline Mosaics of Erica azorica shrubland and Deschampsia foliosa grasslands above the timberline & 7 & 8 & 6 \\
\hline Myrica faya woodlands & 7 & 7 & 12 \\
\hline Myrica faya woodlands or mixed shrubland on volcanic sands & 7 & 7 & 12 \\
\hline Myrica faya woodlands or mixed shrubland of Myrica faya and Juniperus brevifolia & 7 & 7 & 12 \\
\hline Juniperus brevifolia woodlands & 6 & 6 & 11 \\
\hline Mosaics of Juniperus brevifolia woodlands and mixed shrubland on volcanic sands & 6 & 6 & 8 \\
\hline Mosaics of Juniperus brevifolia woodlands and Erica azorica shrubland & 7 & 6 & 4 \\
\hline Juniperus brevifolia woodlands with important patches of Erica azorica shrubland & 7 & 6 & 9 \\
\hline Mosaics of Erica azorica shrubland and Deschampsia foliosa grasslands & 9 & 9 & 11 \\
\hline Mire communities and/or Juniperus brevifolia woodlands & 10 & 10 & 15 \\
\hline Mire communities and/or mosaics of Juniperus brevifolia woodlands and mixed shrubland on volcanic sands & 10 & 10 & 15 \\
\hline Deschampsia foliosa grasslands above the timberline & 8 & 8 & 4 \\
\hline Deschampsia foliosa grasslands above the timberline with vestigial patches of Erica azorica shrubland & 8 & 8 & 4 \\
\hline "Laurifolia" hydrophil forests & 7 & 7 & 12 \\
\hline Mosaics of "Laurifolia" hydrophilic forests and mixed shrubland on volcanic sands & 7 & 7 & 12 \\
\hline "Laurifolia" hydrophilic forests with important patches of Erica azorica shrubland & 8 & 7 & 10 \\
\hline "Laurifolia" ultra-hydrophilic forests & 7 & 7 & 12 \\
\hline Mosaics of "Laurifolia" ultra-hydrophilic forests and mixed shrubland on volcanic sands & 7 & 7 & 12 \\
\hline "Laurifolia" ultra-hydrophilic forests with important patches of Erica azorica shrubland & 8 & 7 & 9 \\
\hline "Laurifolia" mesic forests & 7 & 7 & 12 \\
\hline Mosaics of "Laurifolia" mesic forests and mixed shrubland on volcanic sands & 7 & 7 & 12 \\
\hline "Laurifolia" mesic forests with important patches of Erica azorica shrubland & 8 & 7 & 12 \\
\hline Mixed shrubland of Juniperus brevifolia and Erica azorica & 5 & 5 & 10 \\
\hline Mixed shrubland of Juniperus brevifolia, Erica azorica and other shrubs on volcanic sands & 5 & 6 & 11 \\
\hline Plant communities of ombrotrophic peat bogs & 10 & 10 & 5 \\
\hline
\end{tabular}

CV: Conservation value; PV: Protection value; NCC: Nature conservation cost. 
Table 5

Assignment of BLM values for each scenario.

\begin{tabular}{|c|c|c|c|c|c|c|c|}
\hline Scenario & BLM & $\Delta(\mathrm{SA}-\mathrm{TA})$ & SA (\%) & Max ISA (\%) & Moran's I & $z$-score & $p$-value \\
\hline \multirow[t]{4}{*}{1} & 0.1 & 7279.38 & 63.81 & 37.50 & 0.954 & 155.986 & 0.000 \\
\hline & 0.05 & 5746.23 & 60.36 & 36.80 & 0.954 & 155.893 & 0.000 \\
\hline & 0.01 & 3902.47 & 56.20 & 30.39 & 0.871 & 142.380 & 0.000 \\
\hline & 0.005 & 3915.72 & 56.23 & 29.77 & 0.836 & 136.593 & 0.000 \\
\hline \multirow[t]{4}{*}{2} & 0.1 & 2115.80 & 74.77 & 6.49 & 0.884 & 144.443 & 0.000 \\
\hline & 0.05 & 972.22 & 72.19 & 5.70 & 0.840 & 137.333 & 0.000 \\
\hline & 0.01 & 111.97 & 70.26 & 5.85 & 0.760 & 124.261 & 0.000 \\
\hline & $\mathbf{0}$ & 63.40 & 70.15 & 5.63 & 0.636 & 103.917 & 0.000 \\
\hline \multirow[t]{4}{*}{3} & 0.1 & 4434.17 & 62.90 & 35.73 & 0.930 & 152.010 & 0.000 \\
\hline & 0.05 & 1888.88 & 57.18 & 33.46 & 0.890 & 145.432 & 0.000 \\
\hline & 0.01 & 104.49 & 53.17 & 27.87 & 0.765 & 125.061 & 0.000 \\
\hline & 0.005 & 126.88 & 53.21 & 27.37 & 0.726 & 118.656 & 0.000 \\
\hline \multirow[t]{6}{*}{4} & 0.1 & 135.68 & 70.31 & 5.24 & 0.689 & 112.540 & 0.000 \\
\hline & 0.05 & 148.52 & 70.34 & 5.27 & 0.688 & 112.483 & 0.000 \\
\hline & 0.01 & 45.16 & 70.11 & 5.30 & 0.685 & 112.024 & 0.000 \\
\hline & 0.005 & 6.77 & 70.02 & 5.22 & 0.679 & 110.996 & 0.000 \\
\hline & 0.001 & 5.28 & 70.02 & 5.30 & 0.688 & 112.435 & 0.000 \\
\hline & 0.0005 & 9.97 & 70.03 & 5.29 & 0.692 & 113.040 & 0.000 \\
\hline
\end{tabular}

BLM: boundary length modifier; SA: Selected areas; TA: Target areas; Max ISA: Areas with maximum irreplaceability score; Moran's I: Moran's index.
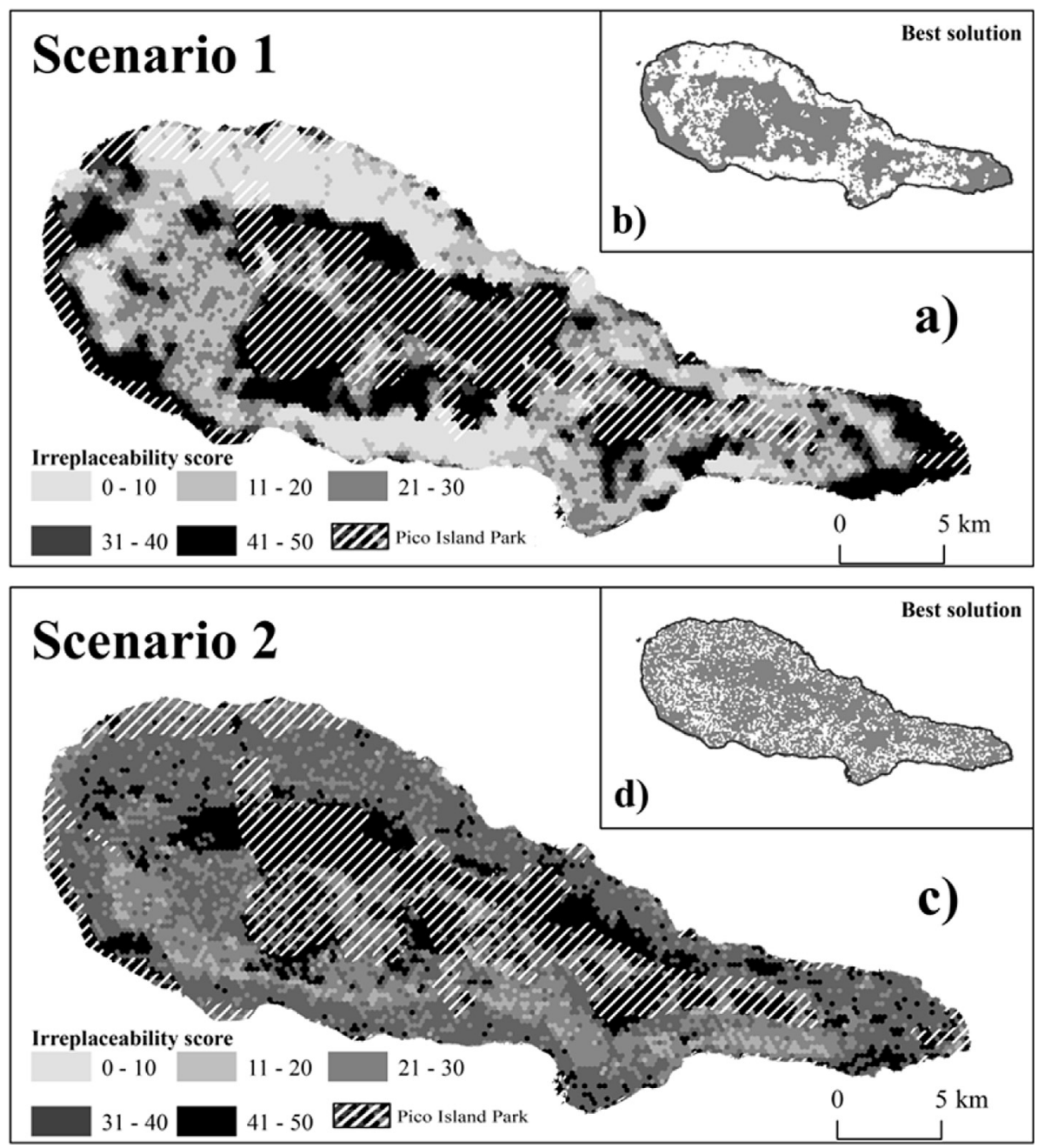

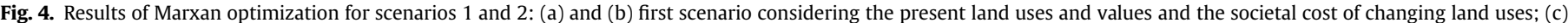

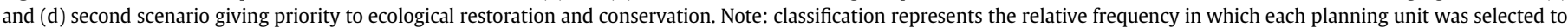
integrate the optimized portfolio.

restoring areas with potential conservation interest (Lagabrielle et al., 2011), such as the invaded areas that may be recovered into natural M. faya forest (Costa et al., 2012).

When considering other typologies of reference vegetation 
communities it can be observed that many of them are not included in the protected area but are partially covered by the best solution given by the model. Giving absolute priority to conservation, without considering land use constraints (Fig. 4c and d), the only differences in management priorities resulted from the qualification of conservation and threat values. Nevertheless, as in any expert classification, error and bias are present (Kynn, 2008; Martin et al., 2012). Moreover, it cannot be considered as an acceptable management alternative, because this option excludes human presence, which is totally unrealistic for the purpose of developing a conservation and management program able to involve all stakeholders. The main advantage of this option is the identification of areas of particular interest for conservation.

\subsection{Comparing management scenarios}

Considering the costs of the investments in restoration and simultaneously preserving areas of economic significance, the results of scenario 3 (Fig. 5a and b) illustrate a clear differentiation between two types of areas: those clearly targeted as areas to be managed towards conservation, and those where the present land uses are considered as having priority over the restoration of the natural vegetation. After analyzing these results, the relevance of protecting agricultural areas and of maintaining the already identified existing values gets clearer. The results of the third scenario differ from those of the first one (Fig. 4a and b) by stressing the importance of recovering the areas presently occupied by invasive species. Thus, this scenario points to two types of target management areas: (1) those that already have high conservation value; and (2) those presenting land cover with negative ecological value but able to be restored according to the corresponding reference vegetation.

Nevertheless, very important habitats (particularly wetlands) were not included in the target management areas because the target for areas with predominant economic value remained high.

In the fourth scenario, implying investment in restoration and considering simultaneously the economic significance of land cover, the soil quality and the need to safeguard given habitats (Fig. $5 \mathrm{c}$ and d), the main targets, point to the recovery of Laurisilvae forest (Arévalo and Fernández-Palacios, 2007) and to the protection of wetlands (Guimarães et al., 2013). As already stressed, the valuation of the different types of reference vegetation is subjective and may, if altered, lead to somewhat different results.

\subsection{Selecting target management areas (TMA)}

Table 6 illustrates the specific land use distribution for each simulated scenario.
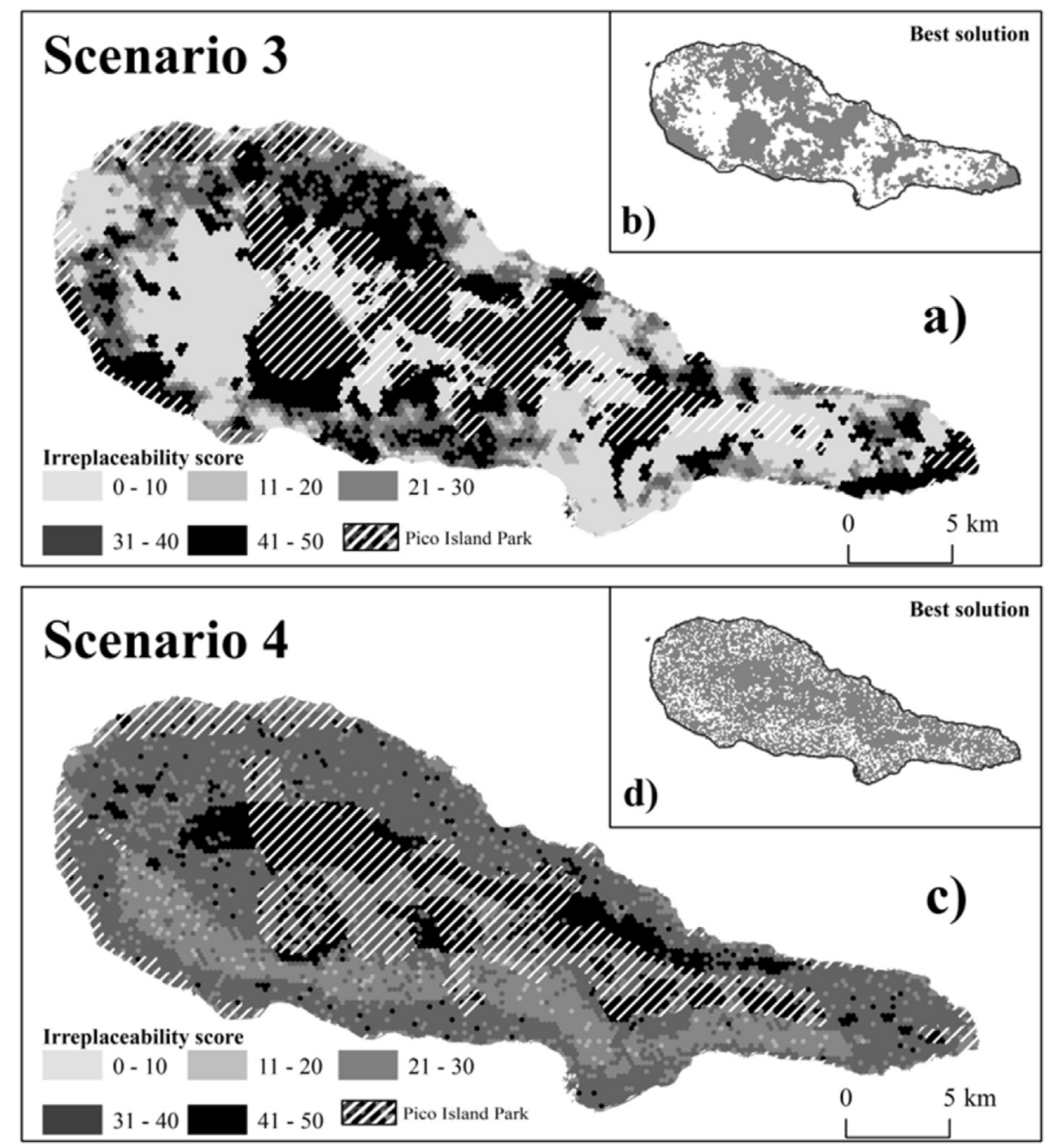

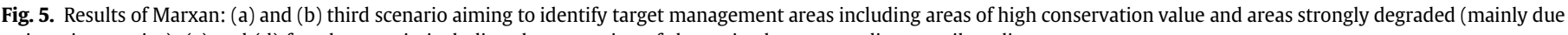
to invasive species); (c) and (d) fourth scenario including the correction of the societal cost according to soil quality. 
Table 6

Land use distribution by scenario.

\begin{tabular}{|c|c|c|c|c|c|c|c|c|c|}
\hline \multirow[t]{3}{*}{ Land use } & \multirow[t]{3}{*}{$\%^{\mathrm{a}}$} & \multicolumn{4}{|c|}{$\begin{array}{l}\text { Scenarios } \\
\text { best solution } \\
(\%)\end{array}$} & \multicolumn{4}{|c|}{$\begin{array}{l}\text { Scenarios } \\
\text { maximum irreplaceability score } \\
(\% \text { b) }\end{array}$} \\
\hline & & S1 & $\mathrm{S} 2$ & S3 & S4 & S1 & S2 & S3 & S4 \\
\hline & & 56.20 & 70.15 & 53.17 & 70.02 & 30.39 & 5.63 & 27.87 & 5.30 \\
\hline Myrica faya communities & 2.27 & 100.00 & 88.77 & 100.00 & 71.10 & 100.00 & 3.77 & 100.00 & 3.50 \\
\hline Erica azorica communities & 9.48 & 100.00 & 90.08 & 100.00 & 78.76 & 99.99 & 12.94 & 99.99 & 11.01 \\
\hline Peatbogs & 0.05 & 100.00 & 100.00 & 100.00 & 100.00 & 100.00 & 100.00 & 100.00 & 100.00 \\
\hline Lagoons & 0.05 & 93.43 & 97.09 & 56.70 & 97.72 & 73.21 & 92.21 & 56.70 & 92.21 \\
\hline Other herbaceous vegetation & 0.87 & 84.62 & 81.34 & 92.97 & 82.35 & 56.04 & 20.45 & 84.02 & 18.74 \\
\hline Vineyards & 3.44 & 89.94 & 72.81 & 40.06 & 55.31 & 49.00 & 3.03 & 19.12 & 3.08 \\
\hline Pastures & 39.60 & 60.06 & 68.92 & 31.47 & 71.07 & 25.09 & 8.45 & 25.41 & 8.23 \\
\hline Other crops & 6.66 & 50.00 & 71.42 & 21.97 & 69.29 & 10.21 & 1.24 & 9.77 & 1.04 \\
\hline Bare rocks & 1.18 & 70.03 & 70.09 & 46.25 & 38.59 & 24.45 & 1.47 & 17.85 & 0.45 \\
\hline Open spaces without vegetation & 3.45 & 90.29 & 80.84 & 90.49 & 79.49 & 81.24 & 3.64 & 38.49 & 2.92 \\
\hline Pinus spp. stands & 1.73 & 30.02 & 76.65 & 86.44 & 70.16 & 13.19 & 0.19 & 15.16 & 0.00 \\
\hline Cryptomeria japonica stands & 1.85 & 32.79 & 69.21 & 66.10 & 71.54 & 19.87 & 5.91 & 23.38 & 6.74 \\
\hline Eucalyptus globulus stands & 0.39 & 25.50 & 40.51 & 66.63 & 55.10 & 15.54 & 0.00 & 17.41 & 0.00 \\
\hline Urban areas & 1.78 & 38.67 & 65.05 & 24.52 & 59.33 & 10.89 & 0.28 & 8.92 & 0.28 \\
\hline Road network & 0.34 & 47.40 & 72.20 & 42.10 & 68.29 & 21.89 & 3.96 & 21.02 & 3.88 \\
\hline Acacia melanoxylon woodland & 1.12 & 32.83 & 66.56 & 83.08 & 67.22 & 17.02 & 2.94 & 16.73 & 2.94 \\
\hline Pittosporum undulatum woodland & 25.74 & 27.30 & 61.01 & 66.29 & 67.89 & 6.04 & 0.78 & 4.73 & 0.76 \\
\hline
\end{tabular}

a Percentage of area of the island.

b Percentage of area of the land use.

Combining both scenarios 3 and 4, and considering the areas with an irreplaceability score above 40 , several Target Management Areas (TMA) with different features and management objectives were obtained (Fig. 6): (1) protection/recovery of Pico Mountain and of the existing vegetation patches of Myrica faya and Erica azorica; (2) protection/recovery of "cloud forest" and of the different wetlands expanded to all drenched areas; (3) protection/ recovery of E. azorica vegetation patches located in the slope deposits of the Pico Mountain; (4) recovery of the areas invaded by Pittosporum undulatum into $M$. faya woodland by potentiating the remaining $M$. faya patches; (5) trading-off presently pastured areas in sensitive and valuable sites (like drenched areas and some cloudforest and E. azorica areas) with areas presently infested by P. undulatum and Acacia melanoxylon or even some forested areas with exotic species such as Eucalyptus or Cryptomeria; (6) protection of coastal escarpments due to their particular geological

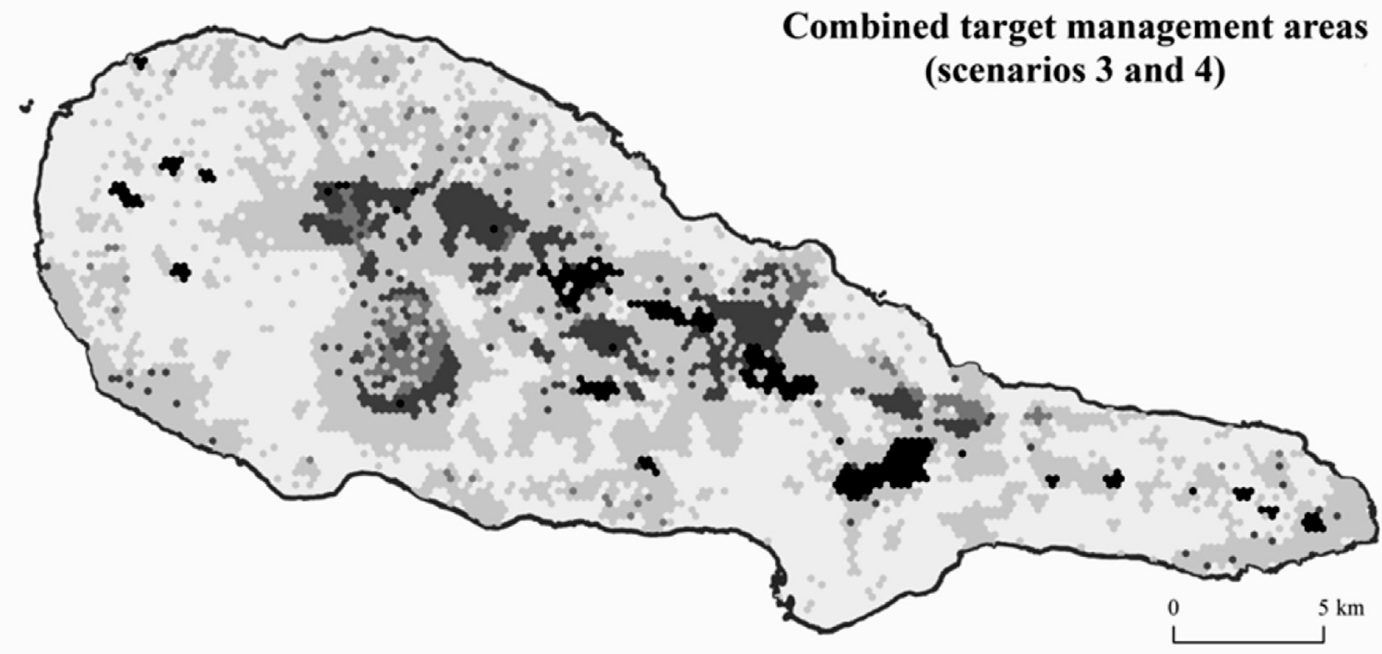

Irreplaceability score $<40$ in both scenarios

Present in only one scenario with irreplaceability score $\geq 40$

Present in two scenarios with irreplaceability score between $[40-50[$

Present in two scenarios with irreplaceability score between [40-50[ (one of them with maximum irreplaceability score)

Present in two scenarios with maximum irreplaceability score

Fig. 6. Combined Target Management Areas (TMA) resulting from scenarios 3 and 4. 
features and natural hazard susceptibility.

This study illustrates how it is possible to define management targets for the whole island, based on an integrated landscape characterization, and using existing methods for the evaluation and prioritization of areas for conservation management. The proposed methodology, developed in a context of limited available information (see also Giakoumi et al., 2011; and Corral-Quintana et al., 2016) presented, for each scenario, different levels of accuracy that must be stressed. In fact, after applying the Pontius metrics (Pontius and Millones, 2011) for assessing the geographical accuracy of results by comparing them with the existing reserves (Fig. 7), it becomes clear that:

1. Within an acceptable level of accuracy, the overlay analysis between current Pico INP boundaries and the simulated reserves extracted from both scenarios 1 and 3 (whose main goal was the maximization of existing values) shows a good agreement and also identifies areas of interest that are not included in the classified areas.

2. Scenarios 2 and 4 , which are especially focused on the maximization of potential values, show similar behaviors in terms of accuracy, emphasizing the fact that they illustrate the need to recover and restore important degraded areas located outside the INP boundaries.

These results clearly illustrate the circumstantiality and subjectivity of current Pico INP boundaries. In sum, Scenario 1 illustrates the deficient (in quantity and quality) incorporation of relevant values. Scenario 2 illustrates the importance of current land use-based conflicts with conservation values. Scenario 3 highlights the importance of the values and land uses' location, as well as their resulting conflicts from the conservation perspective. Scenario 4 is focused on the need of reallocating land uses and natural/naturalized areas towards a better management of the biophysical structure, in order to mitigate/minimize fragmentation effects and maximize the total area with ecological significance, without compromising the economic resources and current and potential (e.g. ecotourism) activities of the island. The results confirmed that agriculture (dominated by extensive grazing) and invasive species are the main constraints for achieving a consistent and coherent systematic conservation planning and management in Pico Island, as observed in other islands of the Azores archipelago (Gil et al., 2013, 2014; Costa et al., 2015). The main conservation issues are the pastures located on and around sensitive areas like wetlands and mires. The reversal of this occupation may be achieved through a trade-off policy based on a more effective use of the most productive soils. This may be achieved by converting pasture occupying sensitive lands into conservation, and by converting lands invaded by $P$. undulatum into pasture. Nevertheless this solution poses a serious cultural problem because of the strong connection existing between land owners and their parcels (ownership), turns any process of land redistribution, definition of intensity and the consequent limitation of grazing activity very complex.

The most problematic zone in Pico is undoubtedly the pastureland located on the northern side of the island which

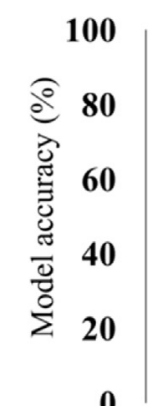

a)
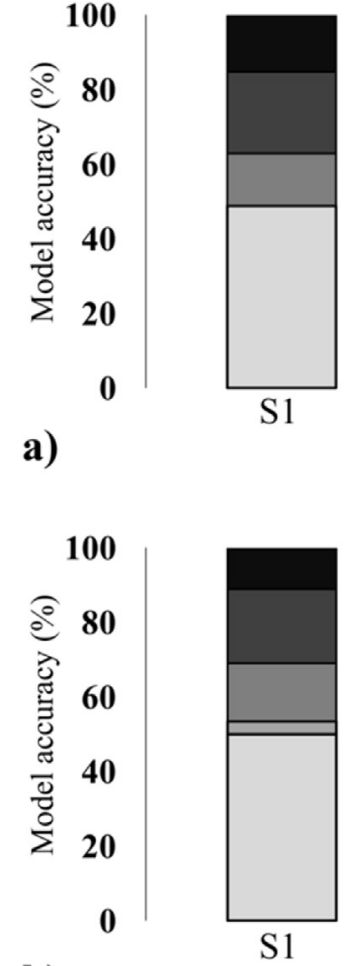

b)
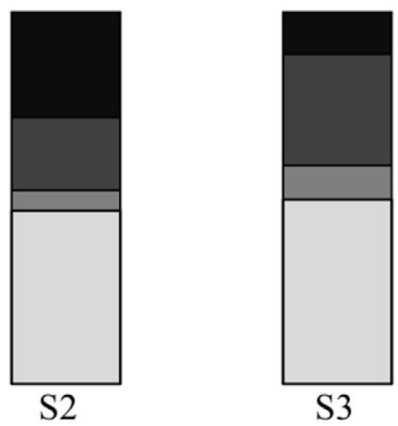

S3

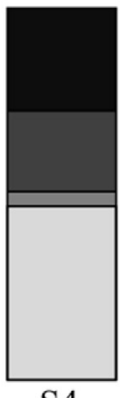

S4

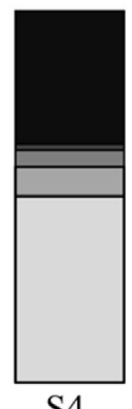

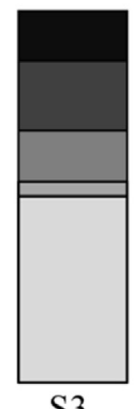

$\mathrm{S} 2$

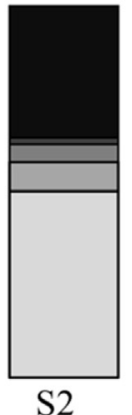

- Disagreement due to quantity

aDisagreement due to location

\section{$\square$ Agreement due to quantity}

$\square$ Agreement due to chance

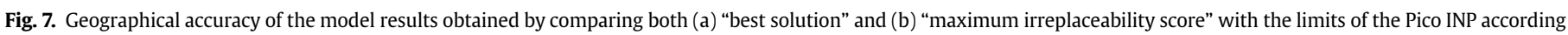
to the metrics proposed by Pontius and Millones (2011). 
corresponds to some of the previously identified TMA. These areas represent more than one third of the total area of pastureland and must, therefore, be carefully handled and managed, in order to simultaneously allow the restoration of Cloud forest areas, coupled with the preservation of areas showing higher grazing productivity. This goal may be achieved through following approaches: (1) differentiation of targets resulting from the combination of scenarios 3 and 4 ; (2) precise location of the different priorities; and (3) determination of the minimal areas able to ensure cohesion and viability to grazing/livestock activity and to native vegetation patches' recovery. These approaches and respective results may be further developed, for instance, by complementing the identified TMA with habitats occupying small areas where particular values occur (e.g. small volcanic formations, wetlands, springs, lakes, deposits with specific geological characteristics).

The need for an integrated approach based on contractualized trade-offs respecting the particular sensibility of islanders (e.g. Petrosillo et al., 2013) is clearly illustrated by the results from the scenario analysis where, only the consensus-based 4th scenario seems to ensure the fulfillment of the conservation policy targets and the potential stakeholder's acceptability and active involvement.

\section{Conclusions}

Considering that the main goal of this research was to develop instruments able to evaluate and compare different management scenarios and their ability to be used as a contribution to the preservation and even increase of conservation value of the terrestrial island's ecosystems as a result of better targeted and stakeholders involved management, it may be stated that the results are positive. An important target was to use previously validated models to assess the existing and potential values, as well as simulate and evaluate land use management alternatives. The results, for the study case, illustrate that:

- It is possible to address the systematic conservation management issues of an entire island, by defining different levels of land use intensity, according to the current or potential value of each site, and by accommodating different valuing perspectives beyond the simple maximization of natural value.

- It possible to develop solid bases for negotiating trade-offs that allow the recovery of important conservation areas without damaging the economic activities.

- The application of these decision-support tools allows the building of a sound basis for a participatory land use reallocation process, by implying the identification and evaluation of management areas according to environmental and societal criteria. In fact, it may be stated that in the study area (Pico Island) it would be possible to achieve such a goal, without compromising the key (core) economic activities directly connected to land use (e.g. grazing/livestock, agriculture, forestry).

- It is also possible to identify specific areas able to be recovered and used in the frame of an integrated management strategy, independently of their current ecological or economic value. This strategy may be materialized, either through the relocation of some grazing/livestock areas currently located near/within highly sensitive habitats, or through the recovery and expansion of native vegetation shrublands/woodlands presently geographically limited, and showing, therefore, low resilience to disturbances.

- It may be possible, through an adequate management of pastureland and recovered native forest patches, to foster and strengthen awareness of landscape management and restoration ecology in Pico Island, with direct, positive and relevant ecological (e.g. progressive eradication of invasive species; mitigation of fragmentation effects; increase of native habitats' spatial coverage; recolonization of native forests by endangered bird species) and socioeconomic impacts (e.g. creation of local specialized jobs; development of highly differentiated and highquality local agricultural products; higher tourism attractiveness).

All these new economic opportunities and their respective potential benefits may be included in a contractualization process aiming at fairly pay each landowner for all the values he is preserving and the services he is providing. In the case of investment cost for conservation/restoration, this procedure will also build trust and ensure accountability.

Finally, these types of decision-support instruments may also constitute a relevant way for ensuring the sustainability and success of any participation process if effective and reliable forms of contracting and accountability are associated and fully implemented.

Therefore, the present methodological approach fulfills all these core requirements and may greatly contribute to a cost-effective participative management of insular environments in order to maximize their conservation value and resilience.

It must nevertheless be stressed that with the available data and in the current research development stage, several important unanswered issues remain, such as the assessment of the economic costs of the specific restoration actions. For instance, removing aliens could be more expensive than preserving semi natural areas in a natural re-growth process.

The conservation/restoration actions and the respective management areas have to be discussed in stakeholders coordinating committees in order to better identify the final conservation and restoration plan and global island management plan to assess the interest and intelligibility of these results and their potential use for a sounder Island Conservation Management.

\section{Acknowledgments}

This project was developed in the frame of the SMARTPARKS research project (reference PTDC/AACAMB/098786/2008) funded by the Portuguese Foundation for Science and Technology (FCT Fundação para a Ciência e Tecnologia). The participation of co-author Artur Gil in this study was supported by a FCT-based Post-Doctoral Research Project (reference SFRH/BPD/100017/2014), funded by the National Budget of the Ministry of Education and Science of Portugal and by the European Social Fund. This study was partially funded by ERFD as part of the Operational Programme for Competitiveness Factors - COMPETE and also received National Funding from the FCT - Foundation for Science and Technology as part of the PEst-C/AGR/UI0115/2011 strategic project.

\section{References}

Arévalo, J.R., Fernández-Palacios, J.M., 2007. Treefall gaps and regeneration composition in the laurel forest of Anaga (Tenerife): a matter of size? Plant Ecol. 188, 133-143. http://dx.doi.org/10.1007/s11258-006-9152-1.

Aretano, R., Petrosillo, I., Zaccarelli, N., Semeraro, T., Zurlini, G., 2013. People perception of landscape change effects on ecosystem services in small Mediterranean islands: a combination of subjective and objective assessments. Landsc. Urban Plan. 112, 63-73. http://dx.doi.org/10.1016/j.landurbplan.2012.12. 010.

Azevedo, E.B., Pereira, L.S., Itier, B., 1999. Modelling the local climate in islands environments: water balance applications. Agric. Water Manag. 40, 393-403. http://dx.doi.org/10.1016/S0378-3774(99)00012-8.

Ball, I.R., Possingham, H.P., Watts, M., 2009. Marxan and relatives: software for spatial conservation prioritisation. In: Moilanen, A., Wilson, K.A., Possingham, H.P. (Eds.), Spatial Conservation Prioritisation: Quantitative Methods and Computational Tools. Oxford University Press, Oxford, 
pp. 185-195.

Bragagnolo, C. Pereira, M., Ng, K., Calado, H., 2016. Understanding and mapping local conflicts related to protected areas in small islands: a case study of the Azores archipelago. Isl. Stud. J. 11 (1), 57-90.

Calado, H., Borges, P., Phillips, M., Ng, K., Alves, F., 2011. The Azores Archipelago Portugal: improved understanding of Small Island coastal hazards and mitigation measures. Nat. Hazards 58, 427-444. http://dx.doi.org/10.1007/s11069010-9676-5.

Calado, H., Vergílio, M., Fonseca, C., Gil, A., Moniz, F., Silva, S.F., Moreira, M., Bragagnolo, C., Silva, C., Pereira, M., 2014. Developing a planning and management system for protected areas on small islands (The Azores archipelago, Portugal): the SMARTPARKS project. J. Integr. Coast. Zone Manag. 14 (2), 335-344. http://dx.doi.org/10.5894/rgci496.

Caujapé-Castells, J., Tye, A., Crawford, D.J., Santos-Guerra, A., Sakai, A., Beaver, K., Lobin, W., Florens, F.B.V., Moura, M., Jardim, R., Gómes, I., Kueffer, C., 2010. Conservation of oceanic island floras: present and future global challenges. Perspect. Plant. Ecol. 12, 107-129. http://dx.doi.org/10.1016/j.ppees.2009.10.001.

Corral-Quintana, S., Legna-de la Nuez, D., Verna, C.L., Hernández, J.H., de Lara, D.R.M., 2016. How to improve strategic decision-making in complex systems when only qualitative information is available. Land Use Policy 50, 83-101. http://dx.doi.org/10.1016/j.landusepol.2015.09.004.

Costa, H., Aranda, S.C., Lourenço, P., Medeiros, V., de Azevedo, E.B., Silva, L., 2012. Predicting successful replacement of forest invaders by native species using species distribution models: the case of Pittosporum undulatum and Morella faya in the Azores. For. Ecol. Manag. 279, 90-96. http://dx.doi.org/10.1016/j. foreco.2012.05.022.

Costa, H., Ponte, N.B., Azevedo, E.B., Gil, A., 2015. Fuzzy set theory for predicting the potential distribution and cost-effective monitoring of invasive species. Ecol. Model. 316, 122-132. http://dx.doi.org/10.1016/j.ecolmodel.2015.07.034.

Costanza, R., Fisher, B., Mulder, K., Liu, S., Christopher, T., 2007. Biodiversity and ecosystem services: a multi-scale empirical study of the relationship between species richness and net primary production. Ecol. Econ. 61, 478-491. http://dx. doi.org/10.1016/j.ecolecon.2006.03.021.

Craig, J.L. 1990. Potential for ecological restoration of islands for indigenous fauna and flora. In: Towns, D.R., Daugherty, C.H., Atkinson, I.A.E. (Eds.), Ecological Restoration of New Zealand Islands. Conservation Sciences Publication n. 2. Department of Conservation, Wellington, pp. 156-165.

Daugherty, C.H., Towns, D.R., Atkinson, A.E., Gibbs, G.W., 1990. The significance of the biological resources of New Zealand islands for ecological restoration. In: Towns, D.R., Daugherty, C.H., Atkinson, I.A.E. (Eds.), Ecological Restoration of New Zealand Islands. Conservation Sciences Publication n. ${ }^{\circ}$ 2. Department of Conservation, Wellington, pp. 9-21.

Dias, E., Mendes, C., Melo, C., Pereira, D., Elias, R., 2005. Azores Central Islands vegetation and flora field guide. Quercetea 7, 123-173.

Dias, N.A., Matias, L., Lourenço, N., Madeira, J., Carrilho, F., Gaspar, J.L., 2007. Crustal seismic velocity structure near Faial and Pico Islands (AZORES), from local earthquake tomography. Tectonophysics 445, 301-317. http://dx.doi.org/10. 1016/j.tecto.2007.09.001.

Elias, R.B., Gil, A., Silva, L., Fernández-Palacios, J.M., Azevedo, E.B., Reis, F., 2016. Natural zonal vegetation of the Azores Islands: characterization and potential distribution. Phytocoenologia 46 (2), 107-123. http://dx.doi.org/10.1127/phyto/ $2016 / 0132$.

ESRI, 2011. ArcGIS Desktop: Release 10. Environmental Systems Research Institute, Redlands.

Fernandes, J.P., Guiomar, N., Soares, A.S., 2006. Geometries in landscape ecology. J. Medit. Ecol. 7 (1-4), 3-13.

Fernandes, J.P., Guiomar, N., Freire, M., Gil, A., 2014. Applying and integrated landscape characterization and evaluation tool to small islands (Pico, Azores, Portugal). J. Integr. Coast. Zone Manag. 14 (2), 243-266. http://dx.doi.org/10. 5894/rgci325.

Fernandes, J.P., Guiomar, N., Gil, A., 2015. Strategies for conservation planning and management of terrestrial ecosystems in small islands (exemplified for the Macaronesian islands). Environ. Sci. Policy 51, 1-22. http://dx.doi.org/10.1016/j. envsci.2015.03.006.

Fernández-Palacios, J.M., de Nascimento, L., Otto, R., Delgado, J.D., García-del-Rey, E., Arévalo, J.R., Whittaker, R.J., 2011. A reconstruction of Palaeo-Macaronesia, with particular reference to the long-term biogeography of the Atlantic island laurel forests. J. Biogeogr. 38, 226-246. http://dx.doi.org/10.1111/j.1365-2699.2010. 02427.x.

Folke, C., Hahn, T., Olsson, P., Norberg, J., 2005. Adaptive governance of socialecological systems. Annu. Rev. Environ. Resour. 30, 441-473. http://dx.doi. org/10.1146/annurev.energy.30.050504.144511.

Fonseca, C., Calado, H., Pereira da Silva, C., Gil, A., 2011. New approaches to environment conservation and sustainability in small islands: the Project SMARTPARKS. J. Coast. Res. SI64, 1970-1974.

Fragoso, M., Trigo, R.M., Pinto, J.G., Lopes, S., Lopes, A., Ulbrich, S., Magro, C., 2012. The 20 February 2010 Madeira flash-floods: synoptic analysis and extreme rainfall assessment. Nat. Hazards Earth Syst. Sci. 12, 715-730. http://dx.doi.org/ 10.5194/nhess-12-715-2012.

Francisco-Ortega, J., Santos-Guerra, A., Kim, S.-C., Crawford, D.J., 2000. Plant genetic diversity in the Canary Islands: a conservation perspective. Am. J. Bot. 87 (7), 909-919. http://dx.doi.org/10.2307/2656988.

Frankham, R., 1998. Inbreeding and extinction: island populations. Conserv. Biol. 12 (3), 665-675. http://dx.doi.org/10.1111/j.1523-1739.1998.96456.x.

Giakoumi, S., Grantham, H.S., Kokkoris, G.D., Possingham, H.P., 2011. Designing a network of marine reserves in the Mediterranean Sea with limited socioeconomic data. Biol. Conserv. 144, 753-763. http://dx.doi.org/10.1016/j.biocon. 2010.11.006.

Gil, A., Yu, Q., Abadi, M., Calado, H., 2014. Using aster multispectral imagery for mapping woody invasive species in pico da vara natural reserve (Azores Islands, Portugal). Rev. Árvore 38 (3), 391-401. http://dx.doi.org/10.1590/S010067622014000300001.

Gil, A., Lobo, A., Abadi, M., Silva, L., Calado, H., 2013. Mapping invasive woody plants in Azores Protected Areas by using very high-resolution multispectral imagery. Eur. J. Remote Sens. 46, 289-304. http://dx.doi.org/10.5721/EuJRS20134616.

Gómez-Baggethun, E., Ruiz-Pérez, M., 2011. Economic valuation and the commodification of ecosystem services. Prog. Phys. Geog. 35 (5), 613-628. http://dx.doi. org/10.1177/0309133311421708.

Guimarães, M.H., Ballé-Béganton, J., Bailly, D., Newton, A., Boski, T., Dentinho, T., 2013. Transdisciplinary conceptual modeling of a social-ecological system - a case study application in Terceira Island. Azores. Ecosys. Serv. 3, e22-e31. http://dx.doi.org/10.1016/j.ecoser.2012.12.007.

Haggar, J.P., 1988. The structure, composition and status of the cloud forests of Pico island in the Azores. Biol. Conserv. 46, 7-22. http://dx.doi.org/10.1016/00063207(88)90106-1.

Heuer, M., 2011. Ecosystem cross-sector collaboration: conceptualizing an adaptive approach to sustainability governance. Bus. Strat. Env. 20, 211-221. http://dx doi.org/10.1002/bse.673.

Hobbs, R.J., Higgs, E., Harris, J.A., 2009. Novel ecosystems: implications for conservation and restoration. Trends Ecol. Evol. 24 (11), 599-605. http://dx.doi.org/10. 1016/j.tree.2009.05.012.

Kynn, M., 2008. The 'heuristics and biases' bias in expert elicitation. J. R. Stat. Soc. A 171 (1), 239-264. http://dx.doi.org/10.1111/j.1467-985X.2007.00499.x.

Lagabrielle, E., Botta, A., Aubert, S., Daré, W., David, D., Fabricius, C., 2010. Modelling with stakeholders to integrate biodiversity conservation with regional land-use planning e lessons learned in Réunion Island. Environ. Model. Softw. 25, 1413-1427. http://dx.doi.org/10.1016/j.envsoft.2010.01.011.

Lagabrielle, E., Rouget, M., Le Bourgeois, T., Payet, K., Durieux, L., Baret, S., Dupont, J. Strasberg, D., 2011. Integrating conservation, restoration and land-use planning in islands - an illustrative case study in Réunion Island (Western Indian Ocean). Landsc. Urban Plan. 101, 120-130. http://dx.doi.org/10.1016/j.landurbplan.2011. 02.004 .

Lagabrielle, E., Rouget, M., Payet, K., Wistebaar, N., Durieux, L., Baret, S., Lombard, A. Strasberg, D., 2009. Identifying and mapping biodiversity processes for conservation planning in islands: a case study in Réunion Island (Western Indian Ocean). Biol. Conserv. 142, 1523-1535. http://dx.doi.org/10.1016/j.biocon.2009. 02.022 .

Lane, M.B., 2007. Towards integrated coastal management in Solomon Islands: identifying strategic issues for governance reform. Ocean. Coast. Manag. 49, 421-441. http://dx.doi.org/10.1016/j.ocecoaman.2006.03.011.

Lindenmayer, D.B., Fischer, J., Felton, A., Crane, M., Michael, D., Macgregor, C. Montague-Drake, R., Manning, A., Hobbs, R.J., 2008. Novel ecosystems resulting from landscape transformation create dilemmas for modern conservation practice. Conserv. Lett. 1, 129-135. http://dx.doi.org/10.1111/j.1755-263X.2008. 00021.x.

Martin, T.G., Burgman, M.A., Fidler, F., Kuhnert, P.M., Low-Choy, S., McBride, M., Mengersen, K., 2012. Eliciting expert knowledge in conservation science. Conserv. Biol. 26 (1), 29-38. http://dx.doi.org/10.1111/j.1523-1739.2011.01806.x.

Mora, C., Sale, P.F., 2011. Ongoing global biodiversity loss and the need to move beyond protected areas: a review of the technical and practical shortcomings of protected areas on land and sea. Mar. Ecol. Prog. Ser. 434, 251-266. http://dx. doi.org/10.1111/cobi.12408.

Mora, J.L., Armas-Herrera, C.M., Guerra, J.A., Rodríguez-Rodríguez, A., Arbelo, C.D. 2012. Factors affecting vegetation and soil recovery in the Mediterranean woodland of the Canary Islands (Spain). J. Arid. Environ. 87, 58-66. http://dx. doi.org/10.1016/j.jaridenv.2012.07.016.

Moran, P.A., 1950. Notes on continuous stochastic phenomena. Biometrika 37 (1-2), 17-23. http://dx.doi.org/10.2307/2332142.

Moreira, M., 2013. Valoração da biodiversidade no Parque Natural de Ilha do Pico através da metodologia InVEST. Relatório Técnico desenvolvido no âmbito do Projeto SMARTPARKS - Sistema de Ordenamento e Gestão de Áreas Protegidas em Pequenas Ilhas (PTDC/AAC-AMB/098786/2008). Universidade dos Açores Ponta Delgada.

Nunn, P., Carson, M., 2015. Collapses of island societies from environmental forcing: does history hold lessons for the future? Glob. Environ. 8 (1), 110-133. http:/ dx.doi.org/10.3197/ge.2015.080106.

Pelling, M., Uitto, J.I., 2001. Small island developing states: natural disaster vulnerability and global change. Global Environ. Chang 3, 49-62. http://dx.doi. org/10.1016/S1464-2867(01)00018-3.

Petrosillo, I., Costanza, R., Aretano, R., Zaccarelli, N., Zurlini, G., 2013. The use of subjective indicators to assess how natural and social capital support residents quality of life in a small volcanic island. Ecol. Indic. 24, 609-620. http://dx.doi org/10.1016/j.ecolind.2012.08.021.

Pinheiro, J., Sampaio, J., Madruga, J., 1987. Carta de capacidade de uso do solo da Região Autónoma dos Açores. Departamento de Clências Agrárias, Universidade dos Açores, Angra do Heroísmo.

Pontius Jr., R.G., Millones, M., 2011. Death to Kappa: birth of quantity disagreement and allocation disagreement for accuracy assessment. Int. J. Remote Sens. 32 (15), 4407-4429. http://dx.doi.org/10.1080/01431161.2011.552923.

Reaser, J.K., Meyerson, L.A., Cronk, Q., de Poorter, M., Eldrege, L.G., Green, E. 
Kairo, M., Latasi, P., Mack, R.N., Mauremootoo, J., O'Dowd, D., Orapa, W., Sastroutomo, S., Saunders, A., Shine, C., Thrainsson, S., Vaiutu, L., 2007. Ecological and socioeconomic impacts of invasive alien species in island ecosystems. Environ. Conserv. 34 (2), 98-111. http://dx.doi.org/10.1017/ S0376892907003815.

Ricketts, T.H., Dinerstein, E., Boucher, T., Brooks, T.M., Butchart, S.H., Hoffmann, M. Lamoreux, J.F., Morrison, J., Parr, M., Pilgrim, J.D., Rodrigues, A.S.L., Sechrest, W. Wallace, G.E., Berlin, K., Bielby, J., Burgess, N.D., Church, D.R., Cox, N., Knox, D. Loucks, C., Luck, G.W., Master, L.L., Moore, R., Naidoo, R., Ridgely, R., Schatz, G.E., Shire, G., Strand, H., Wettengel, W., Wikramanayake, E., 2005. Pinpointing and preventing imminent extinctions. Proc. Natl. Acad. Sci. U.S.A. 102 (51), 18497-18501. http://dx.doi.org/10.1073/pnas.0509060102.

Rijke, J., Brown, R., Zevenbergen, C., Ashley, R., Farrelly, M., Morison, P., van Herk, S. 2012. Fit-for-purpose governance: a framework to make adaptive governance operational. Environ. Sci. Policy 22, 73-84. http://dx.doi.org/10.1016/j.envsci. 2012.06.010.

Schwarz, A.-M., Béné, C., Bennett, G., Boso, D., Hilly, Z., Paul, C., Posala, R., Sibiti, S. Andrew, N., 2011. Vulnerability and resilience of remote rural communities to shocks and global changes: empirical analysis from Solomon Islands. Glob. Environ. Chang. 21, 1128-1140. http://dx.doi.org/10.1016/j.gloenvcha.2011.04. 011.

Seastedt, T.R., Hobbs, R.J., Suding, K.N., 2008. Management of novel ecosystems: are novel approaches required? Front. Ecol. Environ. 6, 547-553. http://dx.doi.org/ $10.1890 / 070046$

Segan, D.B., Game, E.T., Watts, M.E., Stewart, R.R., Possingham, H.P., 2011. An interoperable decision support tool for conservation planning. Environ. Model. Softw. 26, 1434-1441. http://dx.doi.org/10.1016/j.envsoft.2011.08.002.

Smith, J.R., 2016. CLUZ guide version 2.0 (20/2/2016). https://anotherbobsmith. wordpress.com/software/cluz/.
Stewart, R.R., Possingham, H.P., 2005. Efficiency, costs and trade-offs in marine reserve system design. Environ. Model. Assess. 10, 203-213. http://dx.doi.org/ 10.1007/s10666-005-9001-y.

Tallis, H., Ferdana, Z., Gray, E., 2008. Linking terrestrial and marine conservation planning and threats analysis. Conserv. Biol. 22 (1), 120-130. http://dx.doi.org/ 10.1111/j.1523-1739.2007.00861.x.

Triantis, K.A., Borges, P.A.V., Ladle, R.J., Hortal, J., Cardoso, P., Gaspar, C., Dinis, F., Mendonça, E., Silveira, L.M.A., Gabriel, R., Melo, C., Santos, A.M.C., Amorim, I.R., Ribeiro, S.P., Serrano, A.R.M., Quartau, J.A., Whittaker, R.J., 2010. Extinction debt on oceanic islands. Ecography 33 (2), 285-294. http://dx.doi.org/10.1111/j.16000587.2010.06203.x.

Trindade-Filho, J., de Carvalho, R.A., Brito, D., Loyola, R.D., 2012. How does the inclusion of data deficient species change conservation priorities for amphibians in the Atlantic forest? Biodivers. Conserv. 21, 2709-2718. http://dx.doi.org/10. 1007/s10531-012-0326-y.

Tutin, T.G., 1953. The vegetation of the Azores. J. Ecol. 41 (1), 53-61. http://dx.doi. org/10.2307/2257099.

van Beukering, P., Brander, L., Tompkins, E., McKenzie, E., 2007. Valuing the Environment in Small Islands - an Environmental Economics Toolkit. Joint Nature Conservation Comittee. http://www.jncc.gov.uk/page-4065 (viewed Ag. 2013)

Watts, M.E., Ball, I.R., Stewart, R.R., Klein, C.J., Wilson, K., Steinback, C., Lourival, R. Kircher, L., Possingham, H.P., 2009. Marxan with Zones: software for optimal conservation based land- and sea-use zoning. Environ. Model. Softw. 29, 1513-1521. http://dx.doi.org/10.1016/j.envsoft.2009.06.005.

Wiens, J., 2007. The dangers of black-and-white conservation. Conserv. Biol. 21 (5), 1371-1372. http://dx.doi.org/10.1111/j.1523-1739.2007.00695.x.

Wiens, J.A., 2009. Landscape ecology as a foundation for sustainable conservation. Landsc. Ecol. 24, 1053-1065. http://dx.doi.org/10.1007/s10980-008-9284-X. 